Temporal changes in phytoplankton biomass and cellular properties; implications for the IMO Ballast Water Convention

Maria Cecilia Trindade de Castro*1,2,3 and Marcel JW Veldhuis ${ }^{4}$

1: School of Biological and Marine Science, University of Plymouth, Drake Circus, Plymouth PL4 8AA, UK. +44(0)1752600600.

2: Plymouth Marine Laboratory, Prospect Place, Plymouth, PL1 3DH, UK. cdc@pml.ac.uk. $+44(0) 1752633100$.

3: Directorate of Ports and Coasts, Navy of Brazil. Rua Teófilo Otoni, 4 - Centro, 20090-070. Rio de Janeiro / RJ, Brazil.

4: MES, Vroonlant 24, 1791 WK, Den Burg, the Netherlands

* Corresponding author: mctcastro@yahoo.com 


\section{Temporal changes in phytoplankton biomass and cellular properties; implications for the IMO Ballast Water Convention}

Abstract

At two locations, coastal waters of the Wadden Sea, the Netherlands and at the station L4 (Western Channel Observatory) in the English Channel, UK, the temporal size class distribution of the phytoplankton community was investigated with respect to the size classes identified by the International Maritime Organization's Ballast Water Management Convention. As part of this Convention, allowable discharge concentrations of organisms within classes were defined, with the lower size range $(10-50 \mu \mathrm{m})$ consisting mainly of phytoplankton.

Traditional size fractionation methods that use nylon mesh filtration (10 $\mu \mathrm{m}$ mesh) showed considerable size bias. On average $23.1 \%$ of the larger than $10 \mu \mathrm{m}$ cells were still present in the $<10 \mu \mathrm{m}$ filtrate but $21.8 \%$ of the smaller sized cells were also retained on the mesh. In particular the latter would result in an overestimate of the number of cells per mL by as much as a factor of 5.4 .

Flow cytometry was applied to give the precise size classifications of each cell. Temporal measurements, covering an annual cycle, indicated that at both test sites the phytoplankton in the size range 2 to $50 \mu \mathrm{m}$ was dominated by the smaller sized phytoplankton $(<10 \mu \mathrm{m})$. In terms of number of cells that fit the $>10-\leq 50 \mu \mathrm{m}$ size class these were on average only $3.6 \%$ and $2 \%$ in the Wadden Sea and the L4 sampling site, respectively. In terms of chlorophyll biomass they represent $28.7 \%$ and $12 \%$, respectively. This was mainly caused by the cellular increase in chlorophyll concentration which increases in proportion to increasing cell size. In contrast, the mesh filtration method resulted in much higher chlorophyll values for the 10-50 $\mu \mathrm{m}$ size range; $53.7 \%$ in the Wadden Sea and $38 \%$ at station L4. This overestimation appears 
to be caused by cells in 6-10 $\mu \mathrm{m}$ size range being retained on the mesh rather than passing through.

Present findings are relevant in the context of the size class distribution based on flow cytometry and semi-quantification using chlorophyll as proxy for cell density. - Keywords: Ballast Water Management Convention, Flow cytometry, Fluorometry, Chlorophyll, Phytoplankton

\section{Introduction}

With respect to particle size distribution in nature there are several universal laws based on allometric distributions. In many cases they are based on size and physiological or metabolic properties $[1,2]$. In the oceanic environment, a commonly accepted rule is that the numbers of organisms per unit of volume tend to increase exponentially with decreasing size $[3,4,5,6]$. Also, within a phyla or class, sizes can vary considerably. Phytoplankton varies by up to 6 orders of magnitude in size and up to 9 orders of magnitude in volume [7]. Associated with these differences maximum cell density [8] and various cellular properties also co-vary similarly to chlorophyll [9] and even the size of the genome [10].

This cell size to number relationship has recently received new interest as a result of the International Maritime Organization's Ballast Water Management Convention (BWMC) [11]. In order to minimize the spread on non-indigenous organisms through ballast water, this Convention is limiting the number of living organisms in ships' ballast water discharges. To this end, the Convention has defined specific size range distributions including a size range of $>10$ to $\leq 50 \mu \mathrm{m}$. In nature, this size range tends to be dominated by phytoplankton in terms of numbers while other organisms (e.g. microzooplankton) are far less abundant (less than 5\%, unpublished results). However, this only represents a small component of the whole size range compared to the entire range of phytoplankton sizes present in marine or fresh waters. The 
smallest known phytoplankton is only $0.7 \mu \mathrm{m}$ (Prochlorococcus) [12] but other species can reach up to $>2 \mathrm{~cm}$ in the case of colonies or chains [13]. In the latter case and according to the BWMC, the individual should be measured as it is the smallest unit able to reproduce [14]. The main reason for defining a regulation based on allowed concentrations of organisms in ships' ballast discharge has been the fact that many of the toxic or otherwise harmful phytoplankton species are found within this size category. However, a significant number of phytoplankton species, including bloom forming harmful algae, are smaller than $10 \mu \mathrm{m}$ (e.g. Phaeocystis spp., Pfiesteria spp. and Chrysochromulina spp.) [15]. Small sized species also present higher growth rates, which may be an advantage when colonizing a new environment $[16,17]$

Phytoplankton (or specific sub-populations of) biomass and dynamics are generally studied as a whole so the establishment of a fixed size range imposes new criteria on studies. With the exception of phytoplankton blooms, the defined size range has a relatively low numerical abundance relative to smaller sized cells [18]. On the other hand, larger cells possess much higher concentrations of cellular chlorophyll, a cell component commonly used to estimate biomass or even cell density. As chlorophyll concentrations vary hugely with cell size, errors on cell density estimates based on chlorophyll concentrations will be significant. Even within a relatively small size range of $10-50 \mu \mathrm{m}$ the diameter of the cell varies by a factor of 5 and, therefore, the volume of the cells (assuming they are spherical) will vary by a factor of 125 . The present study was conducted in order to examine the application of flow cytometry and fluorometry in characterizing natural phytoplankton communities with special attention to cell size. In addition, the annual variability of cellular properties like cell size and chlorophyll fluorescence combined with the actual size distribution of the cells was also investigated. The study covers a whole year at 2 different locations the Western Wadden Sea in the Netherlands and the Western English Channel in the UK. 


\section{Material and Methods}

\subsection{Area of study}

\subsubsection{Den Oever Harbour (the Netherlands)}

Water samples (ca. $1 \mathrm{~L}$ ) at the test site in Den Oever (Western Wadden Sea, the Netherlands, $52^{\circ} 56.07 ' \mathrm{~N} ; 05^{\circ} 02.19^{\prime} \mathrm{E}-$ Fig.1) were collected weekly during a full year (2016). The harbour is in the inner part of the Wadden Sea, a shallow estuary repeatedly influenced by fresh water input from a nearby lake (Lake IJssel). During the year the temperature varied from 1 to $22{ }^{\circ} \mathrm{C}$, and nutrients $\left(\mathrm{PO}_{4}, \mathrm{NO}_{3}\right.$ and silicate) were depleted from May until the end of September. Whole samples and samples gently filtered over a $10 \mu \mathrm{m}$ mesh filter were analysed within 30 min of collection.

\subsubsection{L4 station (Western English Channel, UK)}

Samples were collected from the coastal station, L4, of the Western Channel Observatory (WCO) in the English Channel, about $13 \mathrm{~km}$ off Plymouth, in waters of approximately 50 metres deep (coordinates $50^{\circ} 15.0^{\prime} \mathrm{N} ; 04^{\circ} 13.0^{\prime} \mathrm{W}$ - Fig. 1) [19]. Relatively open sea characteristics may be found at the L4 site as well as features resulting from the influence of land with the inflow of water with higher concentrations of nutrients coming from rivers [20, $21,22]$.

L4 samples are collected on a weekly basis, weather permitting, for ongoing research projects conducted by the Plymouth Marine Laboratory (PML) and the Marine Biological Association (MBA). These are some of the longest time-series in the world for phytoplankton and zooplankton. In the present study L4 samples were collected from June 2016 to May 2017. 
Water samples from L4 were collected from the surface using a bucket and were analysed immediately or, in a few exceptional instances, samples were kept in a constant temperature room (held at L4 seawater temperature) and were analysed within 18 hours after collection.

Fig. 1: Study area showing Den Oever harbour in the Wadden Sea, The Netherlands $\left(52^{\circ} 56.07^{\prime} \mathrm{N} ; 05^{\circ} 02.19^{\prime} \mathrm{E}\right)$ and the $\mathrm{L} 4$ sampling site in the Western English Channel, UK $\left(50^{\circ} 15.0^{\prime} \mathrm{N} ; 04^{\circ} 13.0^{\prime} \mathrm{W}\right)$

\subsection{Methods}

\subsubsection{Flow cytometry}

Flow cytometry (FCM) is widely applied in biological research including plant cells, yeast, phytoplankton bacteria and viruses [23, 24, 25]. In short, a set of bio-optical parameters is analysed from particles passing a narrowly focussed laser beam. While passing the laser a variety of cell properties related to size (Forward Light Scatter: FS) optical density (Side Scatter: SS) of auto or induced fluorescence are generated by each individual cell. This is done as peak or integrated values, varying with instrumentation. This information can afterwards be analysed semi-quantitatively and allow selective visual clustering of cells with matching values.

Flow cytometric analyses were conducted using a Beckman Coulter (BC) EPICS-XL-MCL in Den Oever and with a Bekton Dickinson (BD) FACSort ${ }^{\mathrm{TM}}$ at PML.. $2 \mathrm{~mL}$ samples were analysed in triplicate, with single values or averages of the triplicates being used for further analysis according to Veldhuis \& Kraay [26].

The settings of the instruments were adapted to display phytoplankton cells in the size range from 2 to $50 \mu \mathrm{m}$. The size was measured as the scattered light in the forward direction (FS), the measurement best related to size [25]. The red fluorescence from the phytoplankton 
chlorophyll was measured after excitation with blue laser light $(488 \mathrm{~nm})$ as autofluorescence of the chlorophyll pigment (emission $>630 \mathrm{~nm}$ ).

Standard spherical beads with known diameters (9.7 and $50 \mu \mathrm{m}$, Polysciences) were used as an internal standard for instrument calibration. These beads are uniform in size with known coefficients of variation (C.V. $<2 \%)$ and measurements should possess the same spread for size and fluorescence.

Data analysis was based on clustering (sub) populations with identical size and chlorophyll fluorescence properties and considering the IMO size classifications, the fixed size defined implies that size rather than a specific population of cells was selected. Since phytoplankton populations usually have a broad size range, even within a species, the implication of this selection may be that only a part of the groups meets the size requirement. Next to cluster analysis resulting in grouped average values of cell size and chlorophyll fluorescence a frequency distribution of the cell size of the entire phytoplankton population was also made. This was done by reducing the standard 1024 channels, covering 4 decades of variation in size, into a 256 channel logarithmic mode, i.e. increasing bin size at the larger size ranges.

\subsubsection{Fluorometry}

Samples collected in Den Oever were analysed for phytoplankton biomass, in terms of chlorophyll fluorescence and photosynthetic efficiency, after dark adaptation using a WALZWater-PAM fluorometer, equipped with a blue excitation LED according to Schreiber [27]. The instrument was calibrated for background fluorescence using $0.2 \mu \mathrm{m}$ filtered water.

This analysis provides an estimate of the chlorophyll- $a$ concentration of the total and $<10 \mu \mathrm{m}$ phytoplankton $\left(\mathrm{F}_{0}\right.$ and $\left.\mathrm{F}_{0<10}\right)$. The difference between both values was used to calculate the chlorophyll- $a$ fluorescence of the $>10 \mu \mathrm{m}\left(\mathrm{F}_{0>10}\right)$ fraction. 
L4 samples were analysed using the Ballast Check 2 PAM fluorometer. This uses two measuring LEDs with multiple turnover to determine organisms' photosynthetic activity. The equipment includes a filtration step $(10 \mu \mathrm{m}$ mesh filter $)$ and based on the measured variable fluorescence it provides an estimated abundance for cells $>10 \mu \mathrm{m}$ based on the conversion of a fluorescence value divided by a set constant value of fluorescence per cell. To estimate the total number of cells we used a $0.2 \mu \mathrm{m}$ filter. Therefore the calculated size fraction in this case is for cells smaller than $10 \mu \mathrm{m}$.

A dark adaptation period of at least 15 minutes was always observed before analyses.

\subsubsection{Size range determination}

Internal standard beads $(9.7 \mu \mathrm{m}$, Polysciences $)$ were used to distinguish between two size classes of phytoplankton (sub) populations combined with a series of size fractionation experiments. These were conducted to establish the relationship between the arbitrary estimates of size, determined as the forward light scatter (FS), and size based on selective filtration.

A suspension of mono algal cultures and samples collected from the field, the latter with clearly distinguishable subpopulations, were gently filtered over a series of filters ranging from 20 to $0.2 \mu \mathrm{m}$. The 20 and $10 \mu \mathrm{m}$ filters were nylon mesh filters with nucleopore filters $(8$, 5, 3, 2, 1 and $0.6 \mu \mathrm{m}$ ) being used for the subsequent filtration steps. During the sequential filtration steps great care was taken that some sample fluid remained on top of the filter and that the filter was not run dry thereby avoiding damage to cells. Three to five replicates of samples were analysed and the number of cells passing through each filter were counted using flow cytometry. Using a logistic (sigmoidal) fit the size, as estimated spherical diameter (ESD), of the cells was determined as the number relating to $50 \%$ retention on the filter according to equation 1 (equation 1) using SigmaPlot (version 12.5). 
Equation 1: $f=\frac{a}{1+\left(\frac{x}{x 0}\right)^{b}}$

- Where $x_{0}=$ infinitive pore size

- $\quad x=$ pore size of filter applied

- $\quad a$ and $b$ computed constants

- $f=$ fraction of cells passing filter

Using this sigmoidal curve fit for each phytoplankton population the average size, as an ESD, was determined using a level of $50 \%$ of the population present. All cultures and field samples used had a length to width ratio of a factor of less than 3 .

Fig. 2: fraction of initial cell number of 4 different phytoplankton species remaining present in filtrate as a function of applied filter pore size. Lines are calculated fit of logistic function. Arrows are associated cell size based on $50 \%$ of cells present.

In total 21 samples, sampled throughout the year in Den Oever, were fully analysed using flow cytometry and the estimated spherical diameter of the phytoplankton subpopulation was compared with the corresponding forward light scatter signal, as a proxy for cell size (Fig. 3). No linear relationship was found but, based on the curve regression fit, the ESD of subpopulation or individual cells can be determined based on the FS measured.

Fig. 3: forward light scatter versus size fractionated estimated spherical cell diameter

\section{Results}

\subsection{Temporal distribution}


Figure 4a shows the annual distribution of phytoplankton numbers in Den Oever with a typical spring and autumn bloom and low cell density in the winter season. The phytoplankton community was throughout the year dominated by smaller sized $(<10 \mu \mathrm{m})$ phytoplankton using the $9.7 \mu \mathrm{m}$ reference beads as a selection criteria for size. In terms of celldensity, the number of phytoplankton cells larger than $10 \mu \mathrm{m}$ varied between 26 and 2662 cells per mL (annual average 982 cells/mL, table 1). Compared to the total number of phytoplankton cells measured, this size class was only a minor fraction of the total, ranging from 0.1 to $14 \%$ (mean value of $3.6 \%$ ).

The L4 site (Figure 4b) showed a similar trend with a distinct spring/summer and autumn blooms and lower numbers during the winter (October to March). Previous studies described the spring and autumn blooms composed mainly by diatoms whilst dinoflagellates are dominant during the summer [28]. The total number of cells per $\mathrm{mL}$ found for the whole period was 12590 in average, however cells larger than $10 \mu \mathrm{m}$ corresponded in average to only 201 cells/mL $(\mathrm{CV} \%= \pm 87$, table 1$)$.

Fig. 4: annual number of total phytoplankton and fraction $<10$ micron (bottom graph). Number and percentage of phytoplankton cells in fraction >10 micron (top graph): Den Oever (a) and L4 (b).

Cell density, cell size of each individual cell and the chlorophyll auto-fluorescence $\left(\mathrm{FO}_{\mathrm{fcm}}\right)$ of each cell were measured concurrently. The collective values of these cellular $\mathrm{F} 0_{\mathrm{fcm}}$ values also provide an estimate of chlorophyll biomass (Fig. 5a, Table 1). The percentage of chlorophyll associated with the larger cell sizes (> $10 \mu \mathrm{m}$ ) varied considerably throughout the year in Den Oever, ranging from 0.8 to $80 \%$ of the total, but the annual mean value of $28.7 \%$ was higher than the value based on cell number. 
Chlorophyll biomass results measured using flow cytometry for L4 samples also showed a similar trend to the pattern found for number of cells (Fig. 5b). And, as experienced in Den Oever, results from the fraction larger than $10 \mu \mathrm{m}$ were higher because larger cells have higher chlorophyll content, showing an average of $12 \%(\mathrm{CV} \%= \pm 108$, Table 1$)$, with values ranging from 3 to $30 \%$ of the total.

Fig. 5: annual flow cytometric integrated chlorophyll concentration of total phytoplankton and fraction $<10 \mu \mathrm{m}$ (bottom graph). Integrated chlorophyll concentration and percentage of chlorophyll in fraction >10 $\mu \mathrm{m}$ (top graph): Den Oever (a) and L4 (b).

The annual analysis of the cellular characteristics of the phytoplankton in Den Oever showed alongside to a variation in terms of numbers also changes in the cellular properties of size (FS) and chlorophyll autofluorescence $\left(\mathrm{FO}_{\mathrm{fcm}}\right)$ (Fig. 6). For the total phytoplankton community these average values varied by as much as a factor of 4 for both size and chlorophyll throughout the year. Using the conversion of equation 1 the corresponding average sizes would range from 5 to $15 \mu \mathrm{m}$ (Fig. 3).

Identical results were measured at station $\mathrm{L} 4$ where the minimum average value represented ca. one quarter of the average values found for cell size and chlorophyll content. While the ratio between maximum and minimum single results varied by a factor of ca. 15 for both cellular properties.

On a more detailed level, and based on a clearly visible subpopulation, flow cytometrically derived values of size and chlorophyll also co-varied indicating a clear relationship between size and chlorophyll content (Fig. 7). This relationship was found for all size classes covering the entire size range of phytoplankton cells in both sampling sites. 
Fig. 6: annual variation in cell size and cellular chlorophyll autofluorescence of total phytoplankton community ( 2 - > 50 micron) and size class > 10 micron: Den Oever (a) and L4 (b).

Fig. 7: Covariation between cell size (measured as forward light scatter) and cellular chlorophyll autofluorescence of total phytoplankton community $(2-50 \mu \mathrm{m})$ and different subpopulations $2-4 \mu \mathrm{m}, 4$ to $7 \mu \mathrm{m}, 7$ to $10 \mu \mathrm{m}$ and $>10 \mu \mathrm{m}$ (Den Oever data - a). Same covariation for the total number of cells ( 2 to $50 \mu \mathrm{m})$ and for organisms between 2 and 10 and from 10 to $50 \mu \mathrm{m}$ (L4 data - b).

Table 1 near here

\subsection{Detailed size classification}

Because flow cytometry generates values of size and chlorophyll fluorescence data for each individual cell, it is possible to generate a complete frequency distribution of the size distribution of each sample analysed (Fig. 8).

This was done based on a logarithmic distribution of the bin-size varying from 2.7 FS units at the lower size range to 340 FS units per bin of the largest bin. Throughout the year the size distribution of the phytoplankton community remained rather constant despite changes in absolute numbers. Only during typical bloom events, in spring or autumn, a relative increase in certain size ranges ( 6 to 8 and 10 to $15 \mu \mathrm{m}$ ) was observed. These were usually related to the episodic occurrence of blooms of mono-specific phytoplankton species. On the basis of the annually averaged values, the highest numbers of phytoplankton fall within the FS size range of 10 to $200 \mu \mathrm{m}$, these values correspond with an ESD ranging from 2 to $20 \mu \mathrm{m}$ (Equation 1) (Fig. 8a).

A frequency histogram of the observed FS values at station L4 is shown in Fig. 8b. At this station the values of FS for total phytoplankton varied from 7.2 to 112.3 and were 
concentrated between 10 and 100 on a logarithmic distribution. Also from L4 data we can see a constant size distribution throughout the year regardless changes in absolute number.

Fig. 8: frequency distribution of cell size of each sampling day in Den Oever (average of 3 replicates, black lines) and annual average \pm 1 sd (right scale) (a) and frequency distribution of cell size for total phytoplankton at station L4 considering all samples/replicates in the period $(\mathrm{N}=114, \mathrm{FS}=28.2 \mathrm{CV} \%= \pm 63)(\mathrm{b})$.

\subsubsection{Size fractionation $10 \mu \mathrm{m}$ mesh}

As mentioned, the IMO's ballast water performance standard (Regulation D-2) provided in the BWM Convention is defined on a size class basis. Having this in mind, the following section describes the results of the samples filtered over $10 \mu \mathrm{m}$ mesh, the commonly applied method to separate size classes, compared to entire sample. Measurements of total phytoplankton biomass (PAM fluorescence, $\mathrm{F}_{0}$ ), cell density and FCM-integrated chlorophyll values based on the mesh separation method resulted in distinct differences when compared to those based on flow cytometric values for size (Figure 5, Table 2). On average, the values based on the filter screening were substantially higher for the $>10 \mu \mathrm{m}$ size fraction at both test sites.

Applying a standard fluorescent measurement showed that $53.7 \%$ of the total phytoplankton chlorophyll fluorescence $\left(\mathrm{PAM}-\mathrm{F}_{0}\right)$ was associated with phytoplankton retained on the $10 \mu \mathrm{m}$ mesh in Den Oever. Therefore the theoretical concentration of cells in the $>10 \mu \mathrm{m}$ size fraction would be 6148 cells $/ \mathrm{mL}$, or $22.7 \%$ of the total. This is 6.2 times higher than measured using flow cytometric size selection $(982$ cells $/ \mathrm{mL}$ ). The FCM-integrated chlorophyll measurements also showed that $47.3 \%$ of the chlorophyll was retained on the $10 \mu \mathrm{m}$ mesh. This percentage is close to the value based on the bulk chlorophyll fluorescence $(53.7 \%)$. 
In addition to the whole water sample, a detailed flow cytometric analysis of size and cellular chlorophyll fluorescence was conducted on the fraction of phytoplankton passing the $10 \mu \mathrm{m}$ mesh (Table 2). Analysis showed that both cells with a flow cytometric determined size of > $10 \mu \mathrm{m}$ were passing the $10 \mu \mathrm{m}$ mesh but also that smaller sized cells were retained on the filter.

On average 227 cells $/ \mathrm{mL}$ were measured that were $>10 \mu \mathrm{m}$ on basis of their size (FS) in the $10 \mu \mathrm{m}$ mesh filtered water samples. Compared to the total number of phytoplankton cells this was only $1.1 \%$ but as much as $23.1 \%$ of the number in the same size range of cells in the unfiltered sample.

Alternatively, an average of 5392 cells/mL were retained on the nylon mesh corresponding to $20.6 \%$ of the total phytoplankton number classified on basis of the FS-size $<10 \mu \mathrm{m}$.

Applying the same procedure for the $\mathrm{L} 4$ data, resulting $\mathrm{F}_{0}$ measurements from the $\mathrm{BC} 2$ fluorometer showed $38 \%$ of the total phytoplankton associated with the fraction over $10 \mu \mathrm{m}$, which would mean an average of 1812 cells $/ \mathrm{mL}$. This is 9 times higher than the 201 cells $/ \mathrm{mL}$ average number detected with FCM and $14.4 \%$ of the total cells in average.

Table 2 near here

The effect of the $10 \mu \mathrm{m}$ mesh filtration on the size distribution of the phytoplankton was also analysed on the level of each individual cell for samples collected in Den Oever, similar to that shown in Fig. 8 for the unfiltered sample. For this analysis the frequency distribution of the cell densityfor the entire year was integrated instead of using the annual average (Fig. 9). The top graph of Fig. 9 shows the size distribution of a cell culture of Tetraselmis sp. (average cell diameter of $12 \mu \mathrm{m}$ ). The detailed cell size analysis showed that, as commonly observed for phytoplankton, the population of Tetraselmis was far from uniform in size distribution and 
varied by as much as a factor 3 . The size of $95 \%$ of the cells varied between values for FS of 80 and 240.

The cell size distribution of the $10 \mu \mathrm{m}$ mesh filtered sample showed values matching those of the unfiltered sample in the lower range of cell sizes up to an FS value of 40. With increasing cell size, the discrepancy in numbers between total and mesh filtered increased even at values of FS below the value corresponding with a cell size of $10 \mu \mathrm{m}$. Above an FS value of 50 the numerical difference between the total and mesh filtered water declined again with increasing cell size. In terms of percentage of reduction in cell density due to the filtration a different trend was observed. At the lowest size ranges the difference was in the order of a few percent increasing to as much as $35 \%$ at the value of FS corresponding to a size of $10 \mu \mathrm{m}$. At the higher cell sizes this percentage increased rapidly. A near $100 \%$ reduction was only measured when the value of FS was higher than a value of 500.

Fig. 9: Flow cytometric data of frequency distribution of phytoplankton cell size (2 - > $50 \mu \mathrm{m})$ of total phytoplankton (top graph), cells passing $10 \mu \mathrm{m}$ mesh, numerical difference and percentage of difference between both data sets. Values are based on annually integrated numbers (below). Top graph is total phytoplankton and Tetraselmis sp. as a reference phytoplankton species. Dashed line indicates FS value corresponding with ESD of $10 \mu \mathrm{m}$.

\section{Discussion}

This study shows that flow cytometry is a useful, fast, accurate and reproducible tool for the size analysis of phytoplankton cells. Size distribution can be done based on the whole community, subpopulation and even as in this case down to the level of the individual cell. 
Although the data for size are usually based on arbitrary units of forward light scatter [10] [25] they can be converted into more realistic values of cell size using simple conversion factors. Jennings \& Parslow [29] defined equivalent spherical diameter as the diameter of a sphere that would perform in the same way as the non-spherical particles presented in the sample; the authors highlight that the resultant dimension is always less than the true major dimension though. These conversions not only rely on the shape/dimensions and their conversion into a forward light scattering signal but also on instrumental differences in how the particle's crosssectional area is determined [30] therefore indicating the need of proper calibration. The measurements also indicate that even within a single phytoplankton species (e.g. Tetraselmis) the variation in size can be considerable, as microscopic analysis confirmed. For many species of phytoplankton analysed the coefficient of variation of size ranged typically between 40 and $60 \%$. The variability in the dimension of size is therefore natural but also explains the overlap when multiple species are present as in the current samples.

Infrequently and during blooms of selective species higher numbers of certain size classes are seen e.g. Phaeocystis or diatoms in the spring in the Wadden Sea [31, 32]. On an annual time scale these blooms are of minor effect on the general pattern of size versus cell number distributions (Fig. 8). At station L4, Tarran \& Bruun [33] described periods of higher abundance for pico- and nanoplankton during the spring / summer in the top 20 meters. The summer peak is probably encouraged by the summer thermocline breakdown allowing the mix of nutrients in the surface layers [34, 33]. Samples from 07 April, 2017 showed the first signs of spring bloom arriving earlier than in recent years, confirmed in subsequent sampling to be dominated by Guinardia delicatula (Dr. Claire Widdicombe - personal communication). L4 results in early May showed very low numbers of cells per mL, probably as a result of being deprived of the nutrients that were consumed by the phytoplankton during the early spring 
bloom (L4 buoy data - PML Western Channel Observatory Blog http://www.westernchannelobservatory.org.uk/blog/?p=870). (Fig. 4 and 5).

These data also confirm the general trend that phytoplankton populations show an inverse relationship between numerical abundance and cell size as has previously been reported in the literature $[35,36,37]$.

On an annual basis, smaller sized cells were dominant at all periods not only at the more offshore station (of the two in this study) L4 (13 Km off Plymouth with influence of the North Atlantic Ocean) but also nearshore in an estuary (Table 1). This dominance is not only restricted to certain periods like the summer when nutrients are normally low [22] but throughout the whole year. Applying the size classification based on the conversion of flow cytometric derived values of size into ESD shows that on average, the relative contribution of cells with a dimension of $10 \mu \mathrm{m}$ or lager to the total cell number was low, only $3.6 \%$ or $2 \%$ for the Wadden Sea and station L4, respectively. Even when taking into account the higher chlorophyll $a$ concentration of larger sized cells only $28.7 \%$ (Wadden Sea) or $12 \%$ (L4) of the chlorophyll is associated with the larger size fraction.

Figure 8 shows that throughout the year and irrespective of the location, coastal or more open ocean, the flow cytometric determination of cell size results in a uniform and continuing pattern of size distribution of the phytoplankton covering the entire range from 2 to $>50 \mu \mathrm{m}$ in diameter. As a result, classification of populations in terms of size classes will therefore be a rather arbitrary exercise. In this study up to $44 \%$ of the Tetraselmis population must be classified as cells with a diameter of less than $10 \mu \mathrm{m}$ (Fig. 9). The rather strict definition used by the BWMC [11] of 'minimum cell dimension' would imply that even within a single species, individual cells would not meet the criteria and exact sizing of all cells would be required. While flow cytometry provides a full-scale analysis of cell size in a time span of 
several minutes, more detailed microscopic analysis of a large number of cells would take many hours.

Our data also show that the commonly applied method of size selection by means of mesh filtration resulted in significantly different results. Reanalysis of the filtered fraction indicated that as much as $23.1 \%$ of the cells or $14.9 \%$ of the chlorophyll $\left(\mathrm{F} 0_{\mathrm{FCM}}\right)$ of phytoplankton cells larger than $10 \mu \mathrm{m}$ passed through the mesh filter. In contrast, $21.8 \%$ of the cells and $43.0 \%$ of the chlorophyll of phytoplankton cells with estimated cell size $<10 \mu \mathrm{m}$ were retained on the mesh filter. In particular, the bias towards smaller sized cells by the filter resulted in an overestimation of the actual numbers by as much as a factor of 5.4. Also in terms of chlorophyll biomass the difference between both size selection methods was considerable. The direct measurement of chlorophyll biomass, applying PAM-fluorescence analysis, resulted in $53.7 \%$ and $38 \%$ of the chlorophyll associated with the larger sized cells in Den Oever and L4 respectively. These values were comparable with the flow cytometric data of differences in chlorophyll (47.3\% and $29 \%$ in Den Oever and L4 respectively). In reality the actual number of cells was much lower, on average only 982 per mL (Den Oever) and 201 per $\mathrm{mL}(\mathrm{L} 4)$; and therefore also their chlorophyll concentration $\left(\mathrm{F} 0_{\mathrm{FCM}}\right.$ of 28.7 and $12 \%$ in Den Oever and L4 respectively).

Finally, we return to the initial questioning on what would be the effect of cell size on the conversion factors used by fluorometers to convert fluorescence into cell density. In theory, any fluorescence parameter may be converted into number of cells $/ \mathrm{mL}$ by means of an internal coefficient. However, variations in cells' size and therefore in the content of chlorophyll within the cell can affect the fluorescence signal measured, which means that a simple conversion value based on chlorophyll fluorescence might not be completely reliable $[10,38,39]$. Another aspect to be considered is the device's behaviour to a large number of 
smaller cells $(<10-\mu \mathrm{m})$, would their fluorescence signal influence fluorometer's numeric results? Since many fluorometers used in the quantification of the IMO relevant size class of $10-50 \mu \mathrm{m}$ include a filtration step, the bias due to smaller size cells retained on the filter may be significant.

On the other hand, based on an uniform distribution of size and numbers, an average cell size and accompanying chlorophyll fluorescence can be calculated. For the Den Oever test site the average cell size, as ESD, determined was $20.8 \mu \mathrm{m}$ (CV $\pm 44 \%$, ranging from 11.6 to $30.0 \mu \mathrm{m})$ and corresponding chlorophyll fluorescence of $329.4 \mathrm{~F} 0_{\mathrm{FCM}} /$ cell $(\mathrm{CV} \pm 85 \%$, ranging from 49.4 to $\left.608.7 \mathrm{~F}_{\mathrm{FCM}} / \mathrm{cell}\right)$. But even for the given coefficient of variation there would be a 12 fold variation in cellular chlorophyll, and with a fixed conversion factor an equal variation in corresponding number of cells.

\section{Conclusion}

This study attempts to add value to the discussion on the possible implications resulting from cellular properties and biomass changes on the IMO's Ballast Water Convention implementation notably on the ballast water performance standard (Regulation D-2). Additionally, it intends to raise the issue of potential sources of error for further refinement of the instruments regarding a relatively unknown area where portable tools developed for verifying ships' compliance to the BWMC may produce dubious / false results [40].

In an ocean threatened by increasing $\mathrm{CO}_{2}$ and many other natural and anthropogenic stressors, cell size composition will be affected and therefore the phytoplankton community structure [7]. This will pose additional challenges for indicative tools developed to measure abundance of photoautotrophic cells in the water. Accordingly, conversion factors based on photosynthetic activity will need to be robust enough to face the challenges of a changing ocean. 
Sampling and analysis of ballast water samples is supposed to be a relatively rare procedure according to the tiered regulatory enforcement approach agreed at IMO. However, considering the challenges, there remains a feeling that there is not enough discussion and research to provide the needed confidence that is required of ballast water monitoring techniques.

\section{Acknowledgements}

The authors would like to express their great appreciation to Mr Tim Fileman for his valuable suggestions to this paper and to Dr Glen Tarran for all his support at PML's flow cytometry facility.

This study is part of a PhD research funded by the National Council for Scientific and Technological Development - CNPq (grant award 200026/2015-1), an agency linked to the Ministry of Science and Technology, in charge of the "Science without Borders Programme" with support from the Directorate-General for Nuclear and Technological Development and the Directorate of Ports and Coasts of the Brazilian Navy.

\section{References}

1. Litchman E, Klausmeier CA, Schofield OM, et al. The role of functional traits and trade- offs in structuring phytoplankton communities: scaling from cellular to ecosystem level. Ecology Letters. 2007;10(12):1170-1181.

2. Litchman E, Klausmeier C, Yoshiyama K. Contrasting size evolution in marine and freshwater diatoms. Proceedings of the National Academy of Sciences. 2009;106(8):2665-2670.

3. Van Valen L. Body size and numbers of plants and animals. Evolution. 1973:27-35.

4. Isao K, Hara S, Terauchi K, et al. Role of sub-micrometre particles in the ocean. Nature. 1990;345(6272):242.

5. Irwin AJ, Finkel ZV, Schofield OM, et al. Scaling-up from nutrient physiology to the size-structure of phytoplankton communities. Journal of Plankton Research. 2006;28(5):459-471. 
6. White EP, Ernest SKM, Kerkhoff AJ, et al. Relationships between body size and abundance in ecology. Trends in Ecology \& Evolution. 2007;22(6):323-330. doi: https://doi.org/10.1016/j.tree.2007.03.007.

7. Finkel ZV, Beardall J, Flynn KJ, et al. Phytoplankton in a changing world: cell size and elemental stoichiometry. Journal of Plankton Research. 2010;32(1):119-137. doi: 10.1093/plankt/fbp098.

8. Agusti S, Duarte CM, Canjield DE. Phytoplankton abundance in Florida lakes: Evidence for the frequent lack of nutrient limitation. Limnology and Oceanography. 1990;35(1):181-187.

9. Geider R, MacIntyre H, Kana T. Dynamic model of phytoplankton growth and acclimation: responses of the balanced growth rate and the chlorophyll a: carbon ratio to light, nutrient-limitation and temperature. Marine Ecology Progress Series. 1997:187-200.

10. Veldhuis MJ, Cucci TL, Sieracki ME. Cellular DNA Content of Marine Phytoplankton Using Two New Fluorochromes: Taxonomic and Ecological Implications1. Journal of Phycology. 1997;33(3):527-541.

11. IMO International Maritime Organization. International Convention for the Control and Management of Ships' Ballast Water and Sediments. London: IMO.

12. Chisholm SW, Olson RJ, Zettler ER, et al. A novel free-living prochlorophyte abundant in the oceanic euphotic zone [10.1038/334340a0]. Nature. 1988 07/28/print;334(6180):340-343.

13. Hoek C, Mann D, Jahns HM. Algae: an introduction to phycology. Cambridge university press; 1995.

14. IMO International Maritime Organization. Guidelines for Ballast Water Sampling (G2). Annex 3 Resolution MEPC. 2008;173(58): 1-16.

15. Gollasch S, David M, Voigt M, et al. Critical review of the IMO international convention on the management of ships' ballast water and sediments. Harmful Algae. 2007 2007/08/01/;6(4):585-600. doi: http://dx.doi.org/10.1016/j.hal.2006.12.009.

16. Kagami M, Urabe J. Phytoplankton growth rate as a function of cell size: an experimental test in Lake Biwa. Limnology. 2001;2(2):111-117.

17. Liebich V, Stehouwer PP, Veldhuis M. Re-growth of potential invasive phytoplankton following UV-based ballast water treatment. Aquatic Invasions. 2012 (1).

18. Chisholm SW. Phytoplankton size. Primary productivity and biogeochemical cycles in the sea. 1992;213:213-237.

19. Smyth T, Atkinson A, Widdicombe S, et al. The Western Channel Observatory. Progress in Oceanography. 2015 2015/09/01/;137(Part B):335-341. doi: https://doi.org/10.1016/j.pocean.2015.05.020.

20. Harvey H. Annual variation of planktonic vegetation, 1933. Journal of the Marine Biological Association of the United Kingdom. 1934;19(2):775-792.

21. Pingree RD, Griffiths DK. Tidal fronts on the shelf seas around the British Isles. Journal of Geophysical Research: Oceans. 1978;83(C9):4615-4622. doi: 10.1029/JC083iC09p04615.

22. Woodward E, Harris C, Al-Moosawi L. Nutrient concentration profiles from long term time series at Station L4 in the Western English Channel from 2000 to 2016. BODC database. 2017.

23. Davey HM, Kell DB. Flow cytometry and cell sorting of heterogeneous microbial populations: the importance of single-cell analyses. Microbiological reviews. 1996;60(4):641-696.

24. Legendre L, Courties C, Troussellier M. Flow cytometry in oceanography 1989-1999: environmental challenges and research trends. Cytometry Part A. 2001;44(3):164-172. 
25. Ormerod MG. Flow Cytometry - a basic introduction. 2015 ed. Redhill, UK:

Published by the author in association with David Novo, De Novo Software; 2009.

26. Veldhuis MJ, Kraay GW. Application of flow cytometry in marine phytoplankton research: current applications and future perspectives. Scientia Marina. 2000;64(2):121-134.

27. Schreiber U. Chlorophyll Fluorescence: New Instruments For Special Applications. In: Garab G. (ed) Photosynthesis: Mechanisms and Effects. Vol. V, pp. 4253-4258. . Vol. Vol. V. Dordrecht: Kluwer Academic Publishers; 1998. ( Garab G. (ed) Photosynthesis: Mechanisms and Effects. ).

28. Southward AJ, Langmead O, Hardman-Mountford NJ, et al. Long-term oceanographic and ecological research in the western English Channel. Advances in marine biology. 2004;47:1-105.

29. Jennings B, Parslow K, editors. Particle size measurement: the equivalent spherical diameter. Proceedings of the Royal Society of London A: Mathematical, Physical and Engineering Sciences; 1988: The Royal Society.

30 Karp- Boss L, Azevedo L, Boss E. LISST- 100 measurements of phytoplankton size distribution: Evaluation of the effects of cell shape. Limnology and Oceanography: Methods. 2007;5(11):396-406.

31. Cadée GC, Hegeman J. Historical phytoplankton data of the Marsdiep. Hydrobiological Bulletin. 1991;24(2):111-118.

32. Philippart CJM, Anadón R, Danovaro R, et al. Impacts of climate change on European marine ecosystems: Observations, expectations and indicators. Journal of Experimental Marine Biology and Ecology. 2011;400(1-2):52-69. doi: http://dx.doi.org/10.1016/j.jembe.2011.02.023.

33. Tarran GA, Bruun JT. Nanoplankton and picoplankton in the Western English Channel: abundance and seasonality from 2007-2013. Progress in Oceanography. 2015;137, Part B:446-455. doi: http://dx.doi.org/10.1016/j.pocean.2015.04.024.

34. Smyth TJ, Fishwick JR, Al-Moosawi L, et al. A broad spatio-temporal view of the Western English Channel observatory. Journal of Plankton Research. 2010;32(5):585601. doi: 10.1093/plankt/fbp128.

35. Cermeño P, Figueiras FG. Species richness and cell-size distribution: size structure of phytoplankton communities. Marine Ecology Progress Series. 2008;357:79-85.

36. Huete-Ortega M, Marañón E, Varela M, et al. General patterns in the size scaling of phytoplankton abundance in coastal waters during a 10-year time series. Journal of Plankton Research. 2010;32(1):1-14.

37. Álvarez E, López-Urrutia Á, Nogueira E, et al. How to effectively sample the plankton size spectrum? A case study using FlowCAM. Journal of Plankton Research. 2011 July 1, 2011;33(7):1119-1133. doi: 10.1093/plankt/fbr012.

38. Bradie J. METEOR Voyage M116/2: Report on performance of ballast water collection and analysis devices. Prepared for BSH (German Federal Maritime and Hydrographic Agency): 130 pages. 2016.

39. Bradie J, Broeg K, Gianoli C, et al. A shipboard comparison of analytic methods for ballast water compliance monitoring. Journal of Sea Research. 2017.

40. Byllaardt JV, Adams JK, Casas-Monroy O, et al. Examination of an indicative tool for rapidly estimating viable organism abundance in ballast water. Journal of Sea Research. 2017. 